ANTIQUITATES MATHEMATICAE

Vol. 10(1) 2016, p. 19-43

doi: $10.14708 /$ am.v10i0.1549

Lech Maligranda (Luleå)

WALERIAn Piotrowski (Warszawa)

\title{
Samuel Fogelson (1902 - po 1941)
}

Streszczenie. Samuel Fogelson to zapomniany w Polsce matematyk i statystyk warszawski oraz agent wywiadu sowieckiego. Brak o nim wzmianki w Słowniku Biograficznym Matematyków Polskich (2003) i w Polskim Stowniku Biograficznym; jest informacja w Wikipedii [3], ale opisana została tam głównie jego działalność szpiegowska, przedstawiona w artykułach A. Poczobuta [6]-[8]. My chcemy przybliżyć osobę Fogelsona jako matematyka i statystyka warszawskiego, który opublikował wiele prac, zwłaszcza ze statystyki opisowej. Staraliśmy się dotrzeć do jego publikacji i osiągnięć w matematyce i statystyce. Wspomnimy też krótko o jego działalności szpiegowskiej na rzecz państwa sowieckiego.

2010 Klasyfikacja tematyczna AMS (2010): 01A72; 01A60.

Stowa kluczowe: matematyka dwudziestego wieku, matematycy w Europie, polska matematyka.

1. Biografia Fogelsona. Samuel Fogelson [Fogielson, Fogelsohn, Fogielsohn], pseudonim „St. Manert”, urodził się 20 października 1902 roku w Warszawie w rodzinie Moszka Fogielsona i Chai-Sary z domu Halbrajch. Nauki początkowe otrzymał w domu, a w 1912 roku wstąpił do siedmioklasowej Szkoły Handlowej Zgromadzenia Kupców miasta Warszawy ( Handlówki”). W 1915 roku otrzymał promocję do czwartej klasy i wraz z rodzicami wyjechał do Rosji, gdzie w 1918 roku ukończył ośmioklasową szkołę handlową w Rostowie nad Donem. W tym samym roku wstąpił jako słuchacz rzeczywisty na Wydział Matematyczno-Fizyczny Uniwersytetu Dońskiego (były rosyjski Uniwersytet Warszawski, ewakuowany został w 1915 roku do Rostowa nad Donem).

W 1920 roku wraz z rodzicami powrócił do Warszawy i zapisał się na Wydział Przyrodniczo-Matematyczny Wolnej Wszechnicy Polskiej (WWP). Studiował przez cztery semestry oraz brał udział w pracach seminarium matematycznego WWP prowadzonego pod kierunkiem Witolda Pogorzelskiego i Stefana Straszewicza. 

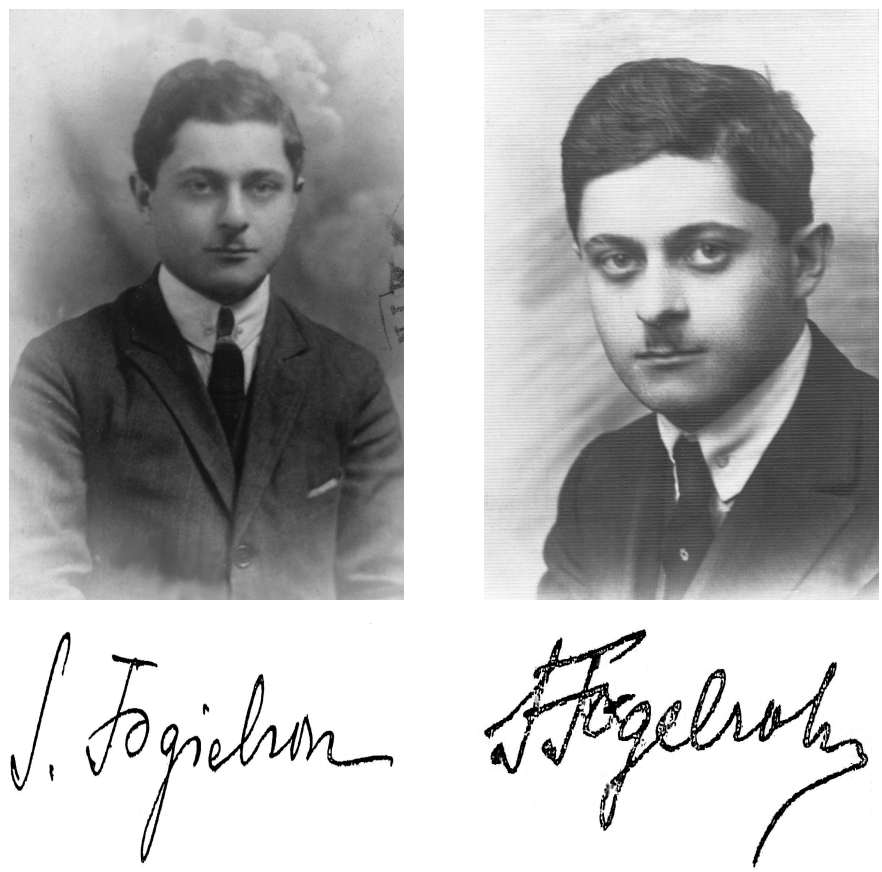

1: Zdjęcia Fogelsona z 1922 roku oraz jego podpisy.

W 1922 roku zdał, jako ekstern, egzamin dojrzałości przed Komisją Egzaminacyjną Kuratorium Warszawskiego Okręgu Szkolnego i w październiku tego roku rozpoczął studia matematyczne na Wydziale Filozoficznym Uniwersytetu Warszawskiego (nr indeksu 13 096, immatrykulowany 30 października 1922 roku). Zamieszkiwał wówczas przy ul. Nowolipie $49 \mathrm{a}$ m. 4 . W ciągu czterech lat wysłuchał całego cyklu wykładów.

W 1925 roku zdał egzamin nauczycielski. W ciągu roku akademickiego 1926/1927 przebywał na urlopie dziekańskim w celu przygotowania pracy magisterskiej. Podczas urlopu podjął pracę nauczycielską w ośmioklasowym Prywatnym Gimnazjum Żeńskim Marii Rubinstein-Dicksteinowej (prawdopodobnie żony syna Samuela Dicksteina - Alfreda) w Warszawie (ul. Leszno 19). Zamieszkiwał wówczas pod adresem ul. Leszno 60 m. 37.

W okresie listopad 1926-styczeń 1927 zdawał na Uniwersytecie Wawszawskim dziewięć egzaminów końcowych z głównych zasad nauk filozoficznych w zakresie matematyki, które, oprócz jednego przedmiotu, zdał na bardzo dobry. Były to kolejno: 15 listopada - algebra u Samuela Dicksteina, geometria analityczna u Kazimierza Żorawskiego (to jedyny przedmiot, który zdał na dobry), rachunek różniczkowy i cał- 


\section{Curriculum vital}

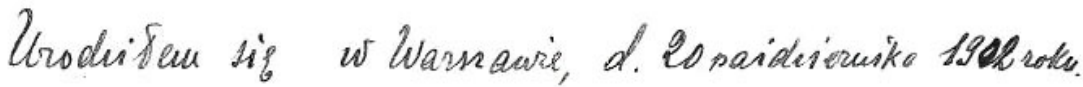

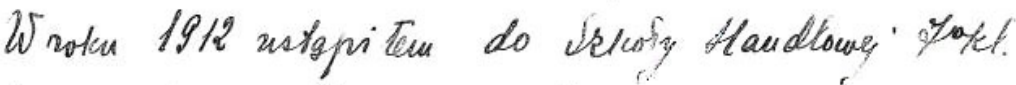

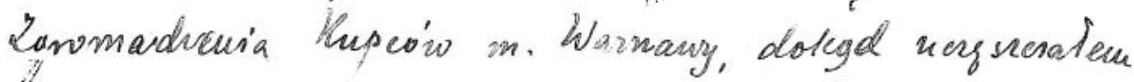

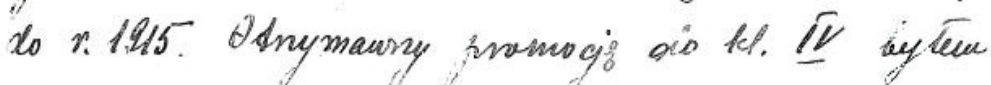
rim ony was a rodricans injechai do Rosi, qhic

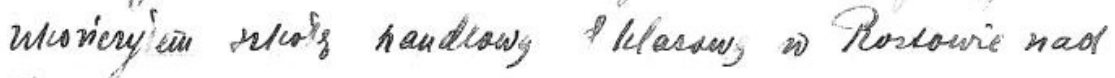

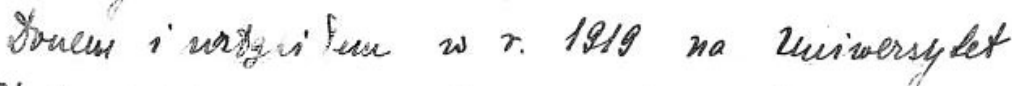

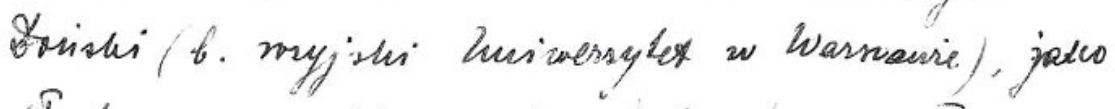

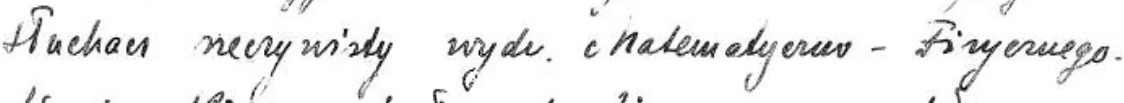

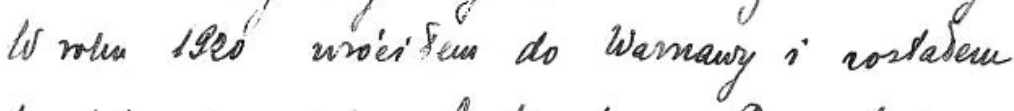
Amyisty na wych. Shatemalyono- Any roduricy

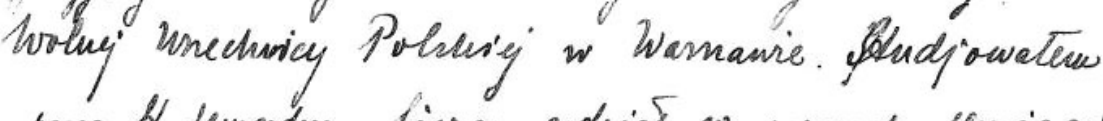

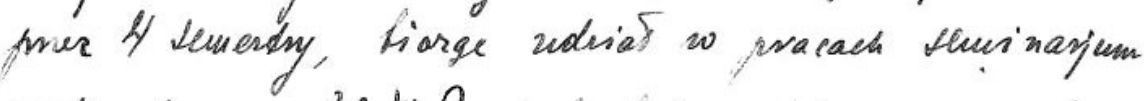
matemadyonego W. W. P. tod tiemnkiem p.p. porf. W. Pogonelsutegu; A. Aranemina. I pacidriernitum

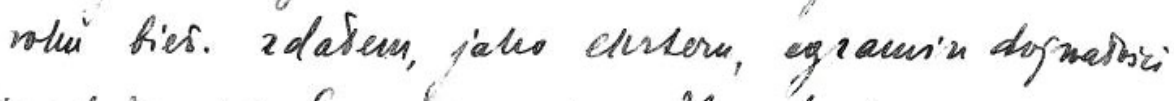
ined koniss/s Eqraininacyjug Kuratojin Varnanskiego Oher. Alubliego.

Wamavad. We 198n.

2: Własnoręczny życiorys Fogelsona z 12 października 1922 roku. 
kowy ze wstępem do analizy u Stefana Mazurkiewicza; 16 listopada mechanika teoretyczna u Antoniego Przeborskiego; 17 listopada - fizyka doświadczalna u Stefana Pieńkowskiego; 18 listopada - główne zasady nauk filozoficznych u Jana Łukasiewicza; 19 listopada - teoria funkcji analitycznych u Stefana Mazurkiewicza. W 1927 roku zdawał kolejno: 20 stycznia - astronomię ogólną u Michała Kamieńskiego; 26 stycznia mechanike teoretyczną u Antoniego Przeborskiego i Stefana Mazurkiewicza. Po przedstawieniu pracy pt. O pewnych rozwiazaniach specjalnych zagadnienia $N$ ciat uzyskał 8 lutego 1927 roku stopień magistra filozofii (dyplom $\mathrm{nr}$ 8).

Po uzyskaniu magisterium zapisał się na Wydział Filozoficzno-Humanistyczny Uniwersytetu Warszawskiego (podanie o przyjęcie złożył 1 kwietnia 1927 roku), gdzie w ciągu trymestru wiosennego studiował filozofię nauk ścisłych, słuchając wykładów Filozofia logiki formalnej u Jana Łukasiewicza, Zagadnienia metodologii nauk u Tadeusza Kotarbińskiego, Etyka u Władysława Tatarkiewicza, Zasady nauczania u Bogdana Nawroczyńskiego i Logika u Kazimierza Ajdukiewicza. Trysemestr wiosenny 1926/1927 został zaliczony 30 czerwca 1927 roku podpisem dziekana Zygmunta Łempickiego.

Jesienią 1927 roku udał się do Paryża (wydaje się, że jego rodzice byli dość majętni, gdyż stać ich było na taki wydatek). Zapisał się tam na studia matematyczne (Sorbona lub Politechnika?) w roku akademickim 1927/1928. 17 lipca 1928 roku ożenił się w Paryżu z Romaną Ferszt (14 czerwca 1900 Warszawa-?), córką Ajzyka Ferszta i Sury Maszy z domu Rotblat. Fogelsonowie zamieszkiwali wówczas w Paryżu przy ul. Thouin 3.

Prawdopodobnie w 1928 roku małżonkowie Fogelson, wracając z Paryża przez Berlin, zatrzymali się u starszego brata Romany - Leona lub młodszego - Ludwika. Odnotujmy, że bracia żony Fogelsona, Leon Ferszt i Ludwik Elizar Ferszt ${ }^{1}$ byli komunistami. Pierwszy z nich był wieloletnim skarbnikiem Komitetu Centralnego Komunistycznej Partii Polski, a drugi szpiegiem sowieckim działającym w Berlinie.

Fogelson podczas pobytu w Berlinie studiował w roku akademickim 1928/1929 na Uniwersytecie Berlińskim. Pierwsza opublikowana praca Fogelsona [F1], jak sam pisze, była wykonana w Instytucie Matematyki Stosowanej Uniwersytetu Berlińskiego. Cytuje w niej Richarda von Misesa (19 kwietnia 1883 Lwów-14 lipca 1953 Boston), dyrektora tego In-

\footnotetext{
${ }^{1}$ Leon Ferszt (7.05.1890 Warszawa-21.04.1957 Warszawa), pseudonimy: „Andrzej Ernst”, „Michalski”, „Paschalski”, „Pruszyński” i Ludwik Elizar Ferszt (1895-1943 Auschwitz), pseudonimy: „Lucjan”, „Lutek”, „Modest”.
} 
1v $8 \ldots .$.

\section{DNTWBASYTET RARSZAESTI}

Tiydzial Filotofiozny

grupa matematyezno-pr zy rodnicza.

DYPLOM MA G IST RA BILOZORT:

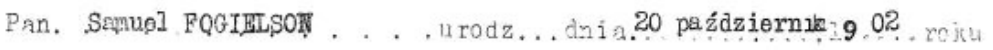
w. . . . . r. z. a . . . . . . . . . . . . . odbyl przepisane studia $\pi$ Uniweryytecie Warszarskim na liydzialo Pilozoficznym w zakresie. . mą t e ma.t.y .k i

i zdał... nast eqpująoe egzaminy:

z .rachunku.różniczkowega i całkomego. . . z trynîkien.

z ze ņstepen dọ anglizy . . . . . . . . . z wy nikiem, bardzo dobrym

z.z.geometrji analitycanej. . . . . . . z aynikiem. dobrym. .

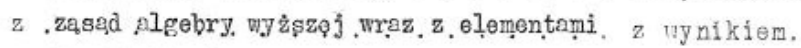

z . tẹorji liçb. . . . . . . . . . . z w wnikien. bardzo dobryn

z mechaniki teoretyennej .I. . . . . . g rynikfen, bardzp dobrym . odezolnoj. . . . . . . . z wynikiom, berdzo dobrym

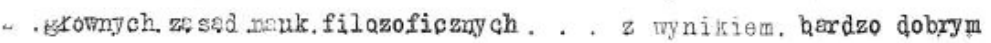

z. toor.ji. funkcyj enalityczuy.ch. . . . . . z wynikiem, bardzo dobrym

z .mechniki teorctyeznej /. egz, ostat.eczny/z wynikien, bardzo dobrym z astronomji.ogolnej . . . . . . . . z pyntiem, bardzo dobrym.

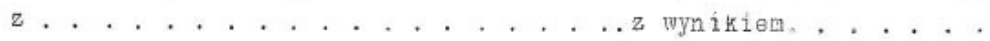

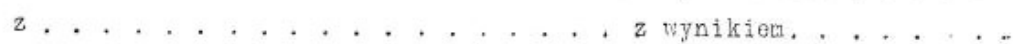

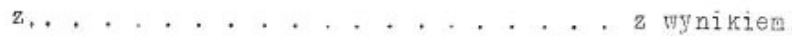

九. . . . . . . . . . z zynikielz.

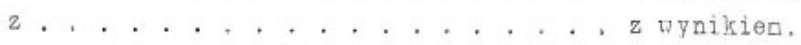

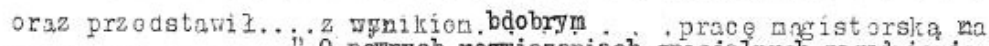
gistorska na temat." ON pewnych rozwiazaniach specjelnych zagadnienia.

Wobec tego Rade Hydziału Rilozofioznogo Jniwersytetu Farszonskiugo na wniosek Komisji Bgzaminacyjnej nadaje Pan.u.

. . Sarueolowi fogielsonowi . . . . . . . . . stopieni m a-

gistra filozofji, jako donód zakofozania przezcón

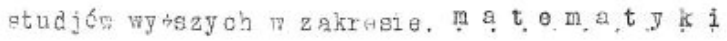

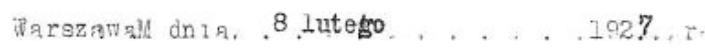
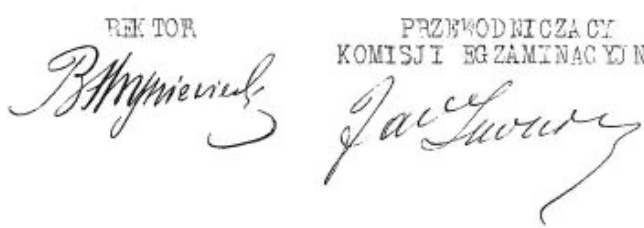

DQIUTAN

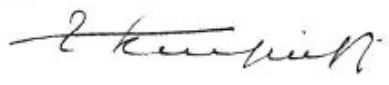

3: Dyplom magistra filozofii z Uniwersytetu Warszawskiego z 8 lutego 1927 roku. 

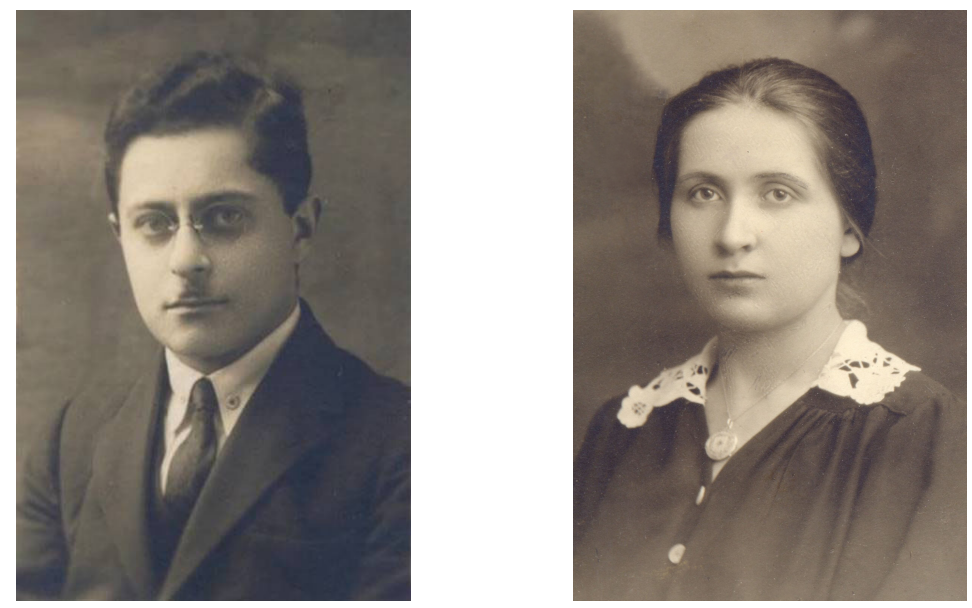

4: Zdjęcie Fogelsona z 1927 roku i jego żony Romany z domu Ferszt.

stytutu w okresie 1919-1933, który twierdził, że matematyka stosowana jest tak samo rygorystyczna jak matematyka czysta. Jednocześnie, pod wpływem Ludwika, został zrekrutowany do siatki szpiegowskiej, a później stworzył swoją siatkę w Polsce.

W 1929 roku Fogelsonowie wrócili do Polski, gdyż świadectwo ślubu zostało przetłumaczone na polski 17 sierpnia 1929 roku (zob. [5]) - ona jako studentka na Wolnej Wszechnicy Polskiej (WWP), a on - jako starszy asystent na WWP. Romana wcześniej studiowała na Wydziale Filozoficznym Uniwersytetu Warszawskiego (1918-1922), ale w roku 1924 zabrała dokumenty i przeniosła się na WWP. Wydaje się, że małżeństwo było bezdzietne.

W końcu listopada 1931 roku powstał Polski Instytut Badania Zagadnień Ludnościowych, blisko związany z Głównym Urzędem Statystycznym. Jego dyrektorem został profesor Ludwik Krzywicki (18591941), a w Zarządzie Instytutu znalazł się między innymi Fogelson (zob. [20, str. 10]). Prawdopodobnie zmianę pracy nakazała centrala w Moskwie. Następnie 8 lat zajmował stanowisko zastępcy kierownika Wydziału Statystyki Ludności w Głównym Urzędzie Statystycznym w Warszawie i przez 4 lata był starszym asystentem na Wydziale Matematyki Uniwersytetu Warszawskiego - tak podobno napisał w kwietniu 1940 roku w autobiografii dla Białostockiego Obwodowego Komitetu $\mathrm{WKP}(\mathrm{b})^{2}$.

W kilku miejscach znajdujemy informację o jego czteroletniej asy-

\footnotetext{
${ }^{2}$ Skrót WKP(b) oznacza Wszechzwiązkową Komunistyczną Partię (bolszewików).
} 
stenturze na Uniwersytecie Warszawskim (zob. [3], [6] - [8], [10]), ale Fogelson nie pracował na tej uczelni, lecz w Wolnej Wszechnicy Polskiej. Dokumenty w [1] zawieraja tylko informacje o jego studiowaniu na UW. Zachowały się tylko niektóre teczki pracownicze na UW, ale brak wśród nich teczki Fogelsona. W żadnym spisie wykładowców i pracowników Uniwersytetu Warszawskiego nie występuje jego nazwisko. Oprócz tego, nie wymienia go Tadeusz Manteuffel w pozycji Uniwersytet Warszawski w latach 1915/16-1934/35: Kronika, Warszawa 1936. Natomiast w [5] znajduje się zaświadczenie dla żony Fogelsona, potwierdzające jego prace na WWP.

2 marca 1938 roku powstała Sekcja Statystyki Ludności. Przewodniczącym został prof. Stefan Szulc ${ }^{3}$, a jego zastępcą - Samuel Fogelson.

15 czerwca 1939 roku odnotowano, że mgr Samuel Fogelson jest członkiem zwyczajnym Polskiego Towarzystwa Statystycznego i zamieszkuje w Warszawie na ul. Kieleckiej $29 \mathrm{~m}$. 2. Dziwne się wydaje, że nie zrobił doktoratu przy takim dorobku naukowym. Przejdźmy jednak do krótkiego omówienia jego działalności wywiadowczej.

Fogelson już od czasów młodości przejawiał sympatie lewicowe, ale nie był członkiem Komunistycznej Partii Polski. W latach dwudziestych związał się z sowieckim wywiadem wojskowym. W podaniu napisanym w 1939 roku do sekretarza Białostockiego Obwodowego Komitetu WKP(b) Igajewa tak opisał swoją działalność (zob. [6], [7]):

Pracując w Głównym Urzędzie Statystycznym w Warszawie i mając dostęp do materiałów, które nie były drukowane $\mathrm{w}$ prasie, systematycznie opracowywałem i układałem dla sztabu RKKA (Rabocze-Krestianskaja Krasnaja Armia) konjukturalne badania stanu gospodarczego byłej Polski. Zazwyczaj robiłem to raz na kwartał. Czasem rzadziej. Te informacje były drukowane w języku polskim na maszynce do pisania, czasem bez podpisu, a czasem za podpisem „St. Manert”. Wydaje mi się, że z nich były robione zdjęcia i przekazywane do Moskwy.

W ciągu kilkunastu lat kierował siatką wywiadowczą w Polsce dostarczając wywiadowi sowieckiemu informacji o stanie gospodarki Polski.

\footnotetext{
${ }^{3}$ Stefan Szulc (19.12.1881 Prażuchy k. Kalisza-12.10.1956 Warszawa), polski ekonomista, statystyk i wykładowca akademicki. Pracował w Wolnej Wszechnicy Polskiej (docent od 1920, profesor nadzwyczajny od 1936), na Uniwersytecie Warszawskim (wykładowca od 1923, profesor nadzwyczajny od 1947), prezes Głównego Urzędu Statystycznego (1945-1949) i od 1947 prezes Polskiego Towarzystwa Statystycznego.
} 
Dość szybko Fogelson awansował na rezydenta wywiadu sowieckiego i odtąd utrzymywał własną siatkę agentów, wśród których byli Alfred Jaroszewicz i Włodzimierz Lechowicz - funkcjonariusze polskich służb specjalnych, ppor. Stanisław Paweł Nienałtowski oraz Henryk Buczyński $^{4}$ (zob. [6]-[8], [10] i [11]).

We wspomnianym już podaniu do sekretarza Igajewa Fogelson pisał jeszcze (zob. [6] i [10, str. 64]):

Ja miałem łączność z grupą towarzyszy, którzy przekazywali informacje o przemyśle wojskowym Polski, a także o niektórych działaniach polskiego sztabu (walka z ruchem komunistycznym w wojsku itd.). Przeze mnie szły dokumenty i pieniądze. Ja spotykałem kurierów, którzy przyjeżdżali do Warszawy. Często sam woziłem te dokumenty z moimi pracami za granicę.

Fogelson twierdził m.in., że dwa razy odwiedził Wiedeń, gdzie miał spotkania z przedstawicielami wywiadu sowieckiego, od których otrzymał zadania i wskazówki dotyczące pracy wywiadowczej. Czasami łączność z centralą utrzymywał brat jego żony, Ludwik Ferszt, który w tym okresie mieszkał w Berlinie (zob. [6], [7] i [10, str. 64]).

Gdy wybuchła II wojna światowa Fogelson, podobnie jak wielu polskich komunistów, przeszedł do sowieckiej strefy okupacyjnej i osiadł w Białymstoku (zob. [2, str. 35]). Jeszcze we wrześniu 1939 roku nawiązał kontakt z NKWD ZSRR ${ }^{5}$, jednak pomimo swoich zasług nie został obdarzony wysokim stanowiskiem (zob. [6]).

W grudniu 1939 roku został zatrudniony jako ekonomista w miejskim urzędzie, gdzie zajmował się planowaniem rozwoju gospodarki miejskiej Białegostoku. Było to stanowisko mało eksponowane i pozbawione realnego znaczenia (zob. [7]).

W 1940 roku Fogelson złożył na ręce sekretarza Białostockiego Obwodowego Komitetu WKP(b) życiorys oraz wniosek o zezwolenie na wyjazd do Moskwy celem kontynuowania kariery zawodowej. Życiorys

${ }^{4}$ Alfred Karol Jaroszewicz (1902-1981), pseudonimy: „Turczyński”, „Adam”, „Gruby”i „Zygmunt”; Włodzimierz Lechowicz (1911-1986), pseudonimy: „Tomasz"i „Morski”; Stanisław Paweł Nienałtowski (1909-2009), pseudonimy: „Walerian”, „Zbroja”, „Michał Jaszczołt”, „Sebastian”i „Tytus”; Henryk Bogusław Buczyński (1901-1945), pseudonimy: „Ryś”i „Stefan”.

${ }^{5}$ NKWD ZSRR to Ludowy Komisariat Spraw Wewnętrznych ZSRR (Narodnyj komissariat wnutriennich dieł SSSR) - centralny organ państwowy (ministerstwo) wchodzący w skład Rady Komisarzy Ludowych - rządu ZSRR, istniejący pod tą nazwą w latach 1917-1946. 
był pozbawiony informacji o współpracy z wywiadem. Moskwa odesłała prośbę do Mińska, a ludowy komisarz edukacji Białoruskiej Socjalistycznej Republiki Radzieckiej Czernow uznał, że Fogelson nie może być wykorzystywany w szkolnictwie wyższym (zob. [6] - [8]).

Jak pisze Poczobut w [6]: Szczegółowy raport, dotyczacy wspótpracy Fogelsona z wywiadem i napisany własnorecznie w 1939 roku dla NKWD, znajduje się w archiwum Grodzieńskiego Obwodowego Działu $K G B$ i nadal jest zamknięty dla niezależnych badaczy. Archiwum Państwowe w Białymstoku odpisało 21 czerwca 2016 roku, że nie posiada autobiografii Fogelsona w swoich zbiorach, natomiast Narodowe Historyczne Archiwum Białorusi w Grodnie nie odpowiedziało na list do niego adresowany.

Nie wiadomo, co się z Fogelsonem działo po wybuchu wojny niemieckosowieckiej. Możliwe, że zginął tuż po wybuchu wojny niemiecko-radzieckiej, nie zdoławszy wydostać się z Białegostoku. Pewne jest, że wojny nie przeżył (zob. [3], [4], [6] - [8] i [10, str. 62]).

2. Dorobek naukowy Fogelsona. Samuel Fogelson był matematykiem zainteresowanym zastosowaniami matematyki i były to: statystyka matematyczna, statystyka ludnościowa i statystyka ekonomiczna. Jerzy Neyman te działy matematyki nazywał statystyką praktyczną, a obecnie jest to statystyka opisowa. Fogelson był autorem ponad 50 prac w dziedzinie matematyki, statystyki oraz demografii. Wśród nich są prace naukowe - 36, prace konferencyjne - 2, wspomnienia pośmiertne - 2, sprawozdanie z konferencji - 1, recenzje książek bądź publikacji - 11, informacja o statystyce $\mathrm{w}$ rolnictwie i przemyśle - 1 i omówienia prac z zagranicznych czasopism statystycznych - 6 .

Przeglądając jego prace, możemy stwierdzić, że nie był on matematykiem teoretykiem, ale raczej statystykiem specjalizującym się w zagadnieniach ludnościowo-ekonomicznych.

Opublikował następujące prace ze statystyki matematycznej: [F1], [F3], [F4], [F13], [F25], [F34] i [F36]. W pierwszej pracy [F1] Fogelson zajmuje się wyznaczeniem mediany dla szeregu statystycznego. Oblicza wartość oczekiwaną (w dawnej terminologii nadzieję matematyczną) mediany $E_{n}$ i średnie odchylenie kwadratowe (dyspersję) mediany $S_{n}$ dla szeregu $2 n+1$ prób podlegających dowolnemu, danemu a priori prawdopodobieństwu, podając wzory

$$
E_{n}=\frac{(2 n+1) !}{(n !)^{2}} \int_{-\infty}^{\infty} x F(x)^{n}[1-F(x)]^{n} d F(x)
$$


oraz

$$
S_{n}=\frac{(2 n+1) !}{(n !)^{2}} \int_{-\infty}^{\infty} x^{2} F(x)^{n}[1-F(x)]^{n} d F(x)-E_{n} .
$$

Ponieważ $n$ jest nieograniczenie rosnące, tzn. rozpatrujemy serię o bardzo wielkiej liczbie prób, wyprowadza on wzory asymptotyczne oraz w części drugiej na kilku przykładach wyznacza medianę dla danych szeregów statystycznych za pomocą interpolacji i szacuje dokładność tego wyznaczania w pewnych przypadkach.

Odnotujmy, że znalezienie mediany zmiennej losowej $X$ oznacza znalezienie wartości $x=m_{e}$, dla której dystrybuanta jest równa $1 / 2$, tzn. $F\left(m_{e}\right)=P\left(X<m_{e}\right)=\frac{1}{2}$. W przypadku ciągłej zmiennej losowej jest to znalezienie pierwiastka równania $\int_{-\infty}^{x} f(t) d t=\frac{1}{2}$. Mediana jest parametrem, który nie zawsze jest wyznaczony w sposób jednoznaczny. Może się nawet zdarzyć, że mediana jest dowolną liczbą z przedziału domkniętego. Praca Fogelsona [F1] jest cytowana w książkach Gumbela [19] i Szulca [28] oraz w pracy Gumbela [18].

W pracy [F3] Fogelson omawia rezultaty z wyrównywania szeregów statystycznych, czyli zastępowania ich przez inne szeregi, o przebiegu bardziej regularnym lub bardziej odpowiadającym istotnym cechom rozpatrywanego zjawiska. Badania takie prowadzili, o czym informuje Fogelson, E. Blaschke $(1893,1906)$, E. T. Whittaker i G. Robinson (1924), J. Fuhrich (1927). W części pierwszej Fogelson omawia ogólne zasady wyrównywania szeregów, podaje zasady klasyfikacji metod wyrównywania, kryteria gładkości szeregu i ocenę skuteczności tych metod. W części drugiej znajdujemy informacje o metodach analitycznych, takich jak metoda najmniejszych kwadratów i metoda momentów oraz ich zastosowanie do szeregów demograficznych. Część trzecia dotyczy metod mechanicznych, wśród których mamy średnią ruchomą z jej uogólnieniami, zniekształcenia systematyczne, metody sumacyjne, metody minimalne i metodę Rhodesa. Ostatnia część omawia metody interpolacyjno-stycznościowe, takie jak metoda Kinga (1914) i metoda Glovera (1921).

Praca [F4] powstała z inicjatywy Instytutu Badania Zagadnień Ludnościowych i zawiera przegląd oraz krytyczne omówienie sposobów badania zagadnień demograficznych metodami matematycznymi.

W pracach [F13], [F25], [F34] i [F36] z kolei Fogelson omawia krzywą koncentracji, często określaną jako krzywa Lorentza, dla ogólnego szeregu rozdzielczego. Szereg rozdzielczy jest statystycznym sposobem prezentacji rozkładu empirycznego. Uzyskuje się go, dzieląc dane statystyczne na pewne kategorie i podając liczebność lub częstość zbiorów danych przypadających na każdą z tych kategorii. Fogelson propo- 
nuje jako „nową” metodę, którą nazywa metodą inwersji, korzystającą z uogólnionych kwantyli zmiennej losowej niezależnej z odpowiednimi uogólnionymi kwantylami zmiennej losowej zależnej. Następnie bada on kilka kwestii w odniesieniu do takich krzywych w stosunku do funkcji rozkładu je generujących. Sugeruje też, by użyć tej metody do innych problemów R. Schmidta.

Kwantyl rzędu $p$, gdzie $0 \leq p \leq 1$, w rozkładzie empirycznym $F(x)=P(X \leq x)$ zmiennej losowej $X$ to taka wartość zmiennej losowej $x_{p}$, dla której spełnione są nierówności

$$
P\left(X \leq x_{p}\right) \geq p \text { oraz } P\left(X \geq x_{p}\right) \geq 1-p .
$$

W szczególności, kwantylem rzędu $p$ jest taka wartość $x_{p}$ zmiennej losowej, że wartości mniejsze lub równe od $x_{p}$ są przyjmowane z prawdopodobieństwem co najmniej $p$, zaś wartości większe lub równe od $x_{p}$ są przyjmowane z prawdopodobieństwem co najmniej $1-p$. Kwantyl rzędu $1 / 2$ to inaczej mediana. [29].

Praca [F13] o miarach koncentracji jest omawiana w artykułach [23],

Równolegle ze statystyką matematyczną Fogelson zajmował się statystyką ludnościową i opublikował wiele prac w tym temacie, a mianowicie: [F2], [F4]- [F6], [F8], [F11], [F12], [F26], [F33], [F37]-[F54] i $[$ F55]-[F57]. Artykuły te są ciągle cytowane. Oto kilka przykładów takich cytowań:

a) Czesław Domański w artykule [15] o zasłużonych statystykach dla nauki, pisząc o Fogelsonie, wyróżnił następujące jego prace ze statystyki: Matematyczna teoria ludności [F4], Miary koncentracji $i$ ich zastosowanie [F13], O interpretacji $i$ zastosowalności miar korelacji [F25] i Z badań nad demografia Polesia $i$ Wotynia [F47].

b) A. Gawryszewski w swojej ponad 600-stronicowej monografii [17] dotyczącej ludności Polski w dwudziestym wieku cytuje wiele prac Fogelsona, a w szczególności prace [F45] (sześciokrotnie), [F40] i [F33].

c) Na trzy artykuły Fogelsona [F41], [F48] i [F54], poświęcone sprawom ludności żydowskiej w Polsce w latach 1919-1939 (strukturze demograficznej i przyrostowi naturalnemu), powołuje się wielu autorów. Wymieńmy tutaj przykładowo książkę Marcusa [22].

d) Praca [F12], opracowana przez zespół Instytutu Badania Zagadnień Ludnościowych w składzie: Stefan Szulc, Samuel Fogelson 
i Ludwik Krzywicki, omawia wyniki prekursorskich na owe czasy badań Instytutu i należy do klasyki demograficznych dzieł. Podane są tutaj metody badań demograficznych.

e) W Google Scholar praca [F47] jest cytowana 10 razy, praca [F40] jest cytowana 9 razy i praca [F46] jest cytowana 6 razy.

Termin wędrówka wewnętrzna z pracy Fogelsona [F53] odnoszący się do ruchów ludnościowych wewnątrz organizmu państwowego przyjął się w literaturze przedmiotu. Pisze Fogelson, że typowymi wędrówkami wewnętrznymi są odpływ ludności wiejskiej do miast w Polsce w latach 1921-1931 oraz ogólne rozmiary migracji wewnętrznych w Polsce. W roku 1921 prawie 1/3 ludności nie mieszkała w miejscu swego urodzenia, przy czym odsetek ten dla miast był prawie dwukrotnie wyższy. Fogelson omawia również wędrówki wewnętrzne w Europie Zachodniej i Ameryce.

Fogelson współpracował z Aleksandrem Rajchmanem (1890-1940). W 1934 roku napisali wspólnie pracę [F29]. Otóż Rajchman w pracy z 1933 roku polemizował z teorią koniunktury Michała Kaleckiego (18991970), a krytyka Rajchmana dotyczyła metody rozwiązania równania Kaleckiego (równania różniczkowego z opóźnionym argumentem). Kalecki w odpowiedzi na zarzuty Rajchmana wyjaśniał swoje tezy, na co Rajchman wspólnie z Samuelem Fogelsonem w [F29] objaśniają bardziej drobiazgowo część matematyczną i ekonomiczną wcześniejszych zarzutów Rajchmana. Dokładniejszy opis znajdziemy w [21].

Ważną częścią działalności naukowej Fogelsona było też publikowanie recenzji książek bądź dłuższych opracowań statystycznych. Napisał 9 recenzji książek: [F7], [F10], [F16], [F17], [F21]-[F23], [F30] i [F58] oraz jedną recenzję 39-stronicowej publikacji - [F15]. Zacytujmy z tej kolekcji kilka fragmentów jego opinii o statystyce oraz o danej publikacji.

O podręczniku von Misesa z rachunku prawdopodobieństwa z 1930 roku stwierdza w [F7, str. 267]:

Obok wielkich zalet natury teoretycznej i metodycznej, o którym wspominaliśmy we wstępie, należy szczególnie podkreślić zalety pedagogiczne podręcznika. Nadzwyczajna jasność i przystępność wykładu, w połączeniu z jego ścisłością i precyzją stawiają książkę Misesa na jednym z pierwszych miejsc $\mathrm{w}$ istniejącej literaturze podręcznikowej przedmiotu. Wszystkie rozdziały książki, zarówno zawierające rzeczy nowe i oryginalne, jak i poświęcone rzeczom znanym, stoją na jednakowo wysokim poziomie staranności opracowania i przejrzy- 
stości wykładu. W rozdziale, poświęconym statystyce, szczególnie podkreślić można doskonale przedstawioną ogólną teorję porównywania szeregów empirycznych z schematami probabilistycznemi oraz wzorowe opracowanie teorji korelacji. $\mathrm{Z}$ pedagogicznego punktu widzenia bardzo też ważny jest szczególnie staranny i szczęśliwy wybór ćwiczeń.

W recenzji [F10] książki Volterry czytamy:

Dla biologa książka Volterry jest ciekawą i wartościową, gdyż daje mu do ręki nowe narzędzie badania, umożliwia stosowanie ścisłych metod matematycznych i otwiera szerokie horyzonty dla dalszych badań. Matematyk natomiast znajdzie w niej, oprócz niezmiernie ciekawego rozszerzenia dziedziny zastosowań znanych mu metod matematycznych, przykłady rzadko spotykanego mistrzostwa w operowaniu metodami elementarnymi.

Z kolei o książeczce Kuczyńskiego tak pisze Fogelson w [F16]:

(...) stawia sobie za zadanie popularyzację nowoczesnych, ścisłych metod mierzenia siły rozrodczej społeczeństwa i jej wyników - przyrostu lub też zmniejszania się liczebności społeczeństwa. (...) W części teoretycznej znajdujemy streszczenie starszych metod Bortkiewicza, oraz podstawy teorji Lotki w postaci obszernego na kilkunastu stronach wypisu z głośnego artykułu Lotki i Dublina. (...) książeczka Kuczyńskiego jest bardzo dobrym wprowadzeniem popularnem w krąg zagadnien, związanych z mierzeniem rozwoju liczebnego ludności.

Francuski Traktat Teorii Prawdopodobieństwa pod redakcją Emila Borela to było zakrojone na wielką skalę przedsięwzięcie, gdyż zaplanowano wydanie 4 tomów w 16 zeszytach. Ocena Fogelsona na temat zeszytu trzeciego z Tomu III, wydanego w 1932 roku, wyrażona w [F17], była następująca:

Wykład zasadniczo poprawny i staranny, aczkolwiek nierówny co do poziomu wymagań, stawianych czytelnikowi: obok rozdziałów zupełnie elementarnych spotykają się części znacznie trudniejsze.

O książce Dunlapa i Kurtza z 1932 roku napisał w [F21]: 
Nomografia (graficzna metoda rachunków) staje się coraz bardziej niezbędnym narzędziem statystyka. (...) Na część trzecią składa się wykaz wzorów statystyki teoretycznej, obejmujący 434 pozycje z ujednostajnionem znakowaniu i z przytoczeniem obfitej literatury. (...) Książka wydana jest bardzo starannie i estetycznie.

W recenzji [F30] omawia Fogelson zawartość trzech tomów książek wydanych przez Instytut Badania Koniunktur Gospodarczych i Cen, stwierdzając na wstępie:

Szacowanie majątku i dochodu społecznego należy niewątpliwie do najbardziej interesujących i ważnych zagadnień statystyki gospodarczej. (...) Z tym większym uznaniem powitać należy wymienioną w nagłównku publikację Instytutu Badania Konjunktur wypełniającą dotkliwą lukę w statystyce naszej i stanowiącą jednocześnie cenny przyczynek do metodologii zagadnienia.

A zakończył recenzję [F30] słowami o estetycznym i przyjemnym wydaniu, zarzucając jednak niestaranną korektę.

O książce Macaulaya uznał w [F22], że:

Książka, przeznaczona dla praktyków i unikających wszelkiego aparatu matematycznego, pomyślana jest dość zręcznie w postaci systematycznego przeglądu szeregu metod wyrównania z równoległymi ilustracjami liczbowymi, przeważnie $\mathrm{w}$ zastosowaniu do tego materjału. (...) Zasadniczo, zdaniem naszem, podstawowe założenie książki jest wadliwe: ma ona być czemś w rodzaju przewodnika przy wyborze metody wyrównania.

O tablicach Elstona z 1932 roku czytamy w [F23]:

Książka podaje rzeczywiście najważniejsze i najbardziej zasadnicze informacje o wszystkich angielskich i amerykańskich tablicach wymieralności.

Artykuł [F55] powstał na podstawie książki Dublina i Lotki, o której Fogelson stwierdza, że:

Wielka sumienność, staranność i wnikliwość analiz jest prawdziwą kopalnią o stosunkach zdrowotnych w Stanach Zjednoczonych. 
Książkę Ludwika Landau z 1938 roku uważa za ważną dla statystyki ekonomicznej, pisząc w swojej recenzji [F58]:

Szacunki dochodu społecznego należą do najtrudniejszych i najbardziej skomplikowanych zagadnień statystyki, zarówno teoretycznej jak i praktycznej. (...) Praca L. Landau daje prawdopodobnie maksimum tego co w dzisiejszym stanie rzeczy ze statystyki wszelkiego rodzaju produkcji można w skali światowej wydobyć. (...) Z tego punktu widzenia omawiana publikacja stanowi niezwykle cenny wkład do polskiej, a może i światowej literatury statystyczno-ekonomicznej.

Znajdujemy jeszcze u Fogelsona w pracy [F19] omówienie referatów ze statystyki teoretycznej wygłoszonych na Międzynarodowym Kongresie Matematycznym, który odbył się w dniach 4-12 września 1932 roku w Zurychu, choć Fogelson nie był obecny na tym Kongresie.

W informacji [F31] stwierdza, że metody statystyczne znajduja w latach ostatnich coraz szersze pole zastosowań w dziedzinie zagadnień natury technicznej, zwiazanych z rolnictwem i przemystem. Wymienia tutaj nazwiska m.in. R. A. Fishera, J. Neymana i E. S. Pearsona.

Oprócz wymienionych kierunków działalności naukowej, kilka pozycji zajmują tablice ludnościowe: [F11], [F49], [F50], [F52]. Fogelsona interesowały nie tylko dane dotyczące Polski, ale także innych rejonów świata. W pracy [F52] Fogelson pokusił się o obliczenia rozmieszczenia ludności w różnych rejonach, opierając się na danych dotyczących powierzchni, liczbie ludności i gęstości zaludnienia poszczególnych jednostek administracyjnych (prowincji, stanów, departamentów, itp) każdego większego kraju. Na pracę tę zwrócił uwagę m.in. S. Szulc [28].

Fogelson napisał dwa wspomnienia pośmiertne. Pierwsze - w 1933 roku [F24] o statystyku francuskim Lucienie Marchu (1859-1933), którego prawdopodobnie spotkał w czasie pobytu w Paryżu, choć nic o tym sam nie pisze. Drugie wspomnienie, napisane w 1934 roku [F32], dotyczyło polskiego matematyka i aktuariusza Henocha Berlinera (18831934), urodzonego w Warszawie.

Na początku 1930 roku Jerzy Neyman, kierownik Zakładu Biometrycznego Instytutu im. Nenckiego i Zakładu Statystyki Matematycznej Szkoły Głównej Gospodarstwa Wiejskiego, przy współpracy statystyków pracujących w wymienionych instytucjach, podjął się prowadzenia „Przeglądu literatury obcej”, zamieszczając w „Kwartalniku Statystycznym" krótkie referaty omawiające zagraniczne publikacje statystyczne. Pierwsze opracowanie ukazało się w zeszycie 1 „Kwartalnika...” w 1930 roku (str. 556-568). W kolejnych opracowaniach zespół autorski 
referatów rozszerzał się, a w 1932 roku prowadzenie „Przeglądu...” objął S. Fogelson razem ze statystykiem Bogusławem Buczyńskim ${ }^{4}$ Ich opracowania ukazały się w sześciu częściach: [F9], [F14], [F18], [F20], [F27] i [F28]. Był to dobry sposób dla młodych ludzi na zapoznanie się z aktualną problematyką badawczą na świecie.

\section{Podziękowania}

Dziękujemy Archiwum Uniwersytetu Warszawskiego za odpłatne przesłanie kserokopii dokumentów [1].

3. Spis prac Samuela Fogelsona. Na prace Samuela Fogelsona składają się: prace naukowe, prace konferencyjne, wspomnienia pośmiertne, recenzje książek i omówienia prac ze statystyki innych autorów.

\section{0}

[F1] Medjana i jej wyznaczanie, „Kwartalnik Statystyczny” 7 (1930), 2, 866-883 (streszczenie po francusku strona 883).

[F2] Robotnicy polscy we Francji w 1927 roku, „Statystyka Pracy” 9 (1930), 4, 381-401.

1931

[F3] O wyrównaniu szeregów statystycznych ze szczególnym uwzględnieniem rozkładu ludności wedtug wieku, „Kwartalnik Statystyczny” 8 (1931), 3, 693-740 (streszczenie po francusku 739-740).

\section{2}

[F4] Matematyczna teorja ludności, „Kwartalnik Statystyczny” 9 (1932), 2, 107134 (streszczenie po francusku 133-134).

[F5] Dokładność szacunku ludności, „Kwartalnik Statystyczny” 9 (1932), 2, 160-161.

[F6] O przeciętnej liczbie dzieci w matżeństwach, „Kwartalnik Statystyczny” 9 (1932), 2, 162-164.

[F7] Nowy podręcznik rachunku prawdopodobieństwa, „Kwartalnik Statystyczny” 9 (1932), 3, 263-267 [jest to recenzja książki R. Misesa, Vorlesungen aus dem Gebiete der angewandten Mathematik, von Richard v. Mises, I Band: Wahrscheinlichkeitsrechnung und ihre Adwendung in der Statistik und der theoretischen Physik, Leipzig-Wien 1930, x+574 str.]

[F8] Emigracja polska we Francji wedtug danych powszechnego spisu ludności 7 marca 1926 roku, „Statystyka Pracy” 11 (1932), 1, 68-72.

[F9] Przeglad obcych czasopism statystycznych, „Kwartalnik Statystyczny” 9 (1932), 4, 325-354 (wspólnie z B. Buczyńskim) [prace od numeru 1 do 383 na 30 stronach]. 
[F10] Recenzja książki: Vito Volterra, Lecons sur la théorie mathématique de la lutte pour vie, Gauthier-Villars et C-ie, Paris 1931, vi+214, „Wiadomości Matematyczne" 34 (1932), 98-104.

\section{3}

[F11] Tablice wymieralności województw poznańskiego i pomorskiego 1927 roku, „Wiadomości Aktuarjalne" 1933, 2, 147-161.

[F12] Badania nad rozrodczościa w Polsce. Część 1: Metoda badań, ewangelickie kolonje rolnicze na Wolyniu, domy robotnicze i urzednicze w Warszawie, Polski Instytut Badania Zagadnień Ludnościowych, Warszawa 1933, vi+89 stron (http://statlibr.stat.gov.pl, wspólnie z S. Szulcem). Jest to przedruk z: „Kwartalnik Statystyczny” 10 (1933), 1, 53-141 (po polsku 53-137, streszczenie po francusku 138-141).

[F13] Miary koncentracji i ich zastosowania, „Kwartalnik Statystyczny” 10 (1933), 1, 149-197 (streszczenie po francusku strona 197).

[F14] Przeglad obcych czasopism statystycznych, „Kwartalnik Statystyczny” 10 (1933), 1, 199-220 (wspólnie z B. Buczyńskim) [prace od numeru 384 do 593 czyli 209 prac na 21 stronach].

[F15] Recenzja publikacji: République Francaise-Présidence du Conseil-Sous-Secréteriat d'Etat de l'Économie Nationale-Statistique Générale de la France, „Table de mortalité des ouvriers mineurs 1923-1928”, Paris 1939, 39 str., „Kwartalnik Statystyczny” 10 (1933), 2-3, 363-364.

[F16] Recenzja książki: Robert R. Kuczyński, Fertility and Reproduction. Methods of Measuring the Balance of Births and Deaths, Falcon Press, New York 1932, 94 str., „Kwartalnik Statystyczny” 10 (1933), 2-3, 364-366.

[F17] Recenzja książki: Emil Borel, Traité du Calcul des Probabilitiés et de ses Applications, avec la collaboration de C.-V.-L. Charlier, R. Deltheil, P. Dubreil, M. Fréchet, H. Galbrun, J. Haag, R. Lagrange, F. Perrin, R. Risser, C.-E. Traynard, Tome III: Les Applications de la Théorie des Probabilités aux Sciences Economiques et aux Sciences Biologiques, Fascicule III: Applications de la Statistique à la Démographie et à la Biologie, par R. Risser, Gauthier-Villars, Paris 1932, x+255 str., "Kwartalnik Statystyczny” 10 (1933), 2-3, 366.

[F18] Przeglad obcych czasopism statystycznych, „Kwartalnik Statystyczny” 10 (1933), 2-3, 373-392 (wspólnie z B. Buczyńskim) [prace od nru 594 do 811 czyli 218 prac na 20 stronach].

[F19] Międzynarodowy Kongres Matematyczny, „Kwartalnik Statystyczny” 10 (1933), 2-3, 394-395 [jest to sprawozdanie z części statystycznej na Międzynarodowym Kongresie Matematycznym w Zurychu (4-12.11.1932)].

[F20] Przeglad obcych czasopism statystycznych, „Kwartalnik Statystyczny” 10 (1933), 4, 507-533 (wspólnie z B. Buczyńskim) [prace od numeru 812 do 1059 czyli 247 prac na 24 stronach]. 
[F21] Recenzja książki: Jack W. Dunlap, Albert K. Kurtz, Handbook of Statistical Nomographs. Tables and Formulas, World Book Company, New York 1932, x+164 str., „Kwartalnik Statystyczny” 10 (1933), 4, 542-543.

[F22] Recenzja książki: Frederick R. Macaulay, The Smoothing of the Time Series, Publications of the National Bureau of Economic Research, Nr. 19, New York 1931, 172 str., „Kwartalnik Statystyczny” 10 (1933), 4, 543-544.

[F23] Recenzja książki: James S. Elston (Principal Constructor), Sources and Characteristics of the Principal Mortality Tables", Revised Edition (Actuarial Studies Nr. 1), Actuarial Society of America, New York 1932, iv+172 str., „Kwartalnik Statystyczny” 10 (1933), 4, 544.

[F24] Lucien March (1859-1933). Wspomnienie pośmiertne, „Kwartalnik Statystyczny" 10 (1933), 4, 548-549.

\section{4}

[F25] O interperetacji $i$ zakresie stosowalności miar korelacji, „Kwartalnik Statystyczny" 11 (1934), 1, 1-38 (streszczenie po francusku 36-38).

[F26] O częstości występowania sieroctwa, „Kwartalnik Statystyczny” 11 (1934), 1, 96-112 (streszczenie po francusku 108-112).

[F27] Przeglad obcych czasopism statystycznych, „Kwartalnik Statystyczny” 11 (1934), 1, 144-182 (wspólnie z B. Buczyńskim) [prace od numeru 1060 do 1325 czyli 266 prac na 39 stronach].

[F28] Przeglad obcych czasopism statystycznych, „Kwartalnik Statystyczny” 11 (1934), 2, 325-356 (wspólnie z B. Buczyńskim) [prace od numeru 1327 do 1550 czyli 223 prace na 32 stronach].

[F29] Jeszcze o jednej z matematycznych teoryj „koniunktury”, „Kwartalnik Statystyczny" 11 (1934), 3-4, 562-594 (wspólna z A. Rajchmanem).

[F30] Recenzja książek: Instytut Badania Kojunktur Gospodarczych i Cen. Badania nad Dochodem Społecznym w Polsce, Warszawa 1934; t. 1. Michał Kalecki i Ludwik Landau, Szacunek Dochodu Społecznego w r. 1929 (str. 54); t. 2. Ludwik Landau, Dochody z Pracy Najemnej w r. 1929 (str. 59); t. 3. Jan Wiśniewski, Rozkład Dochodów wedtug Wysokości w r. 1929 (str. 100), „Kwartalnik Statystyczny” 11 (1934), 3-4, 613-620.

[F31] Nowa dziedzina działalności Royal Statistical Society. Zastosowanie statystyki w rolnictwie i przemyśle, „Kwartalnik Statystyczny” 11 (1934), 3-4, 627-628.

[F32] Dr H. Berliner (1883-1934). Wspomnienie pośmiertne, „Kwartalnik Statystyczny" 11 (1934), 3-4, 628-629.

[F33] Wędrówki międzynarodowe na tle kryzysu gospodarczego, „Statystyka Pracy” 14 (1935), 1, 21-36. 
[F34] Sur la méthode d'inversion en statistique mathématique, C. R. $2^{\text {me }}$ Congrès Math. Pays slaves, „Časopis pro pěstování matematiky a fysiky” 64 (1935), 6, 207-209 (po francusku), JFM 61.1330.07.

1936

[F35] International migrations during the economic crisis, „Baltic Countries” 2 (1936), 2, 201-213 (przetłumaczył A. Truszkowski).

[F36] Quelques remarques sur les courbes de concentration, „Annales de l'Université de Lyon" Section A Sciences mathématiques et astronomie 1 (1936), 3, 69-88, (po francusku), Zbl 0015.22005.

[F37] Noworodki martwe z porodów wielorakich, „Zdrowie Publiczne” 51 (1936), 9, 839-855.

[F38] Urodzenia wielorakie w Polsce na tle międzynarodowym, [w:] „Zagadnienia demograficzne Polski”, ,Statystyka Polski”, Seria C, GUS, Warszawa (1936), 41, 174-208 (streszczenie po francusku 207-208).

[F39] Ruch naturalny ludności na Polesiu: referat zgłoszony na I-szy Zjazd Sprawozdawczo-Naukowy poświęcony Ziemiom Wschodnim, Instytut Badań Narodowościowych, Warszawa 1936, 134 strony „Sprawy Narodowościowe” 10 (1936), 4-5, 341-478.

\section{7}

[F40] Rola wędrówek w rozwoju demograficznym Polski, „Ekonomista” 1 (1937), $55-77$.

[F41] Przyrost naturalny ludności żydowskiej w Polsce, „Sprawy Narodowościowe” 11 (1937), 3-4, 405-419.

[F42] Wychodźctwo z Polski w 1936 roku, „Statystyka Pracy” 16 (1937), 1, 4-7.

[F43] Polacy we Francji w 1931 r., „Statystyka Pracy” 16 (1937), 4, 237-274.

[F44] Wydawnictwa Głównego Urzędu Statystycznego oświetlajace stosunki narodowościowe $i$ wyznaniowe w Polsce, „Sprawy Narodowościowe” 11 (1937), 6, 615-635.

\section{8}

[F45] Ludność, [w:] Encyklopedia Nauk Politycznych. Zagadnienia społeczne, polityczne $i$ gospodarcze, (E. J. Reyman, red. nacz.), Biblioteka Polska, t. 3, Wydawnictwo Instytutu Społecznego i Instytutu Wydawniczego, Warszawa 1938, 599-695, 746-774.

[F46] Les migrations et leur role démographique en Pologne (1871-1936), [w:] Congrès International de la Population Paris 1937, IV. Démographie Stastistique, Hermann, Paris 1938, IV 126-IV 137 (po francusku).

[F47] Z badań nad demografia Polesia $i$ Wotynia, Prace Wydziału PopulacyjnoMigracyjnego nr 6, Instytut Badań Spraw Narodowościowych, Warszawa 1938. 
[F48] Struktura demograficzna ludności żydowskiej w Polsce, Instytut Badań Spraw Narodowościowych. Prace Wydziału Populacyjno-Migracyjnego, Nr 7, Warszawa 1938 „Sprawy Narodowościowe” 12 (1938), 6, 555-588.

[F49] Polskie tablice wymieralności 1931/1932, „Statystyka Polski”, Seria C, 91, stron 7 (wspólna z S. Szulcem).

[F50] Tablice demograficzne, [w:] Ludność, [w:] Encyklopedia Nauk Politycznych. Zagadnienia społeczne, polityczne i gospodarcze, (E. J. Reyman, red. nacz.), Biblioteka Polska, t. 3, 4, Wydawnictwo Instytutu Społecznego i Instytutu Wydawniczego, Warszawa 1938, punkt B w haśle „Ludność, 599-610.

[F51] Spisy i szacunki ludności, [w:] Ludność, [w:] Encyklopedia Nauk Politycznych. Zagadnienia społeczne, polityczne i gospodarcze, (E. J. Reyman, red. nacz.), Biblioteka Polska, t. 3, 4, Wydawnictwo Instytutu Społecznego i Instytutu Wydawniczego, Warszawa 1938, punkt C w haśle „Ludność”, 610-626.

[F52] Historia, rozmieszczenie i struktura ludności, [w:] Ludność, [w:] Encyklopedia Nauk Politycznych. Zagadnienia spoleczne, polityczne i gospodarcze, (E. J. Reyman, red. nacz.), Biblioteka Polska, t. 3, 4-5, Wydawnictwo Instytutu Społecznego i Instytutu Wydawniczego, Warszawa 1938, punkt D w haśle „Ludność”, 626-695.

[F53] Wędrówki, [w:] Ludność, [w:] Encyklopedia Nauk Politycznych. Zagadnienia społeczne, polityczne i gospodarcze, (E. J. Reyman, red. nacz.), Biblioteka Polska, t. 3, 4-5, Wydawnictwo Instytutu Społecznego i Instytutu Wydawniczego, Warszawa 1938, punkt G w haśle „Ludność”, 746-774.

[F54] Ludnościowe wędrówki Żydów w Polsce, „Di Jidise Ekonomik” ${ }^{6}$, Vol. 2, 1938, nr. 3-4, 18-25 i 116-124.

[F55] Postęp w dziedzine zdrowotności, „Warszawskie Czasopismo Lekarskie" 15 (1938), 10, 196-198. Artykuł opracowany na podstawie książki: Louis I. Dublin, Alfred J. Lotka, Twenty-Five Years of Health Progress, Metropolitan Life Insurance Company, New York 1937, xii+611 str.

[F56] Rozrodczość w krajach europejskich, „Warszawskie Czasopismo Lekarskie” 15 (1938), nr 21-22, 421-423; nr 23-24, 444-446; nr 25-26, 468-470.

[F57] O mierzeniu wspótzależności cech dwuwartościowych, „Przegląd Statystyczny” 1 (1938), 262-263.

[F58] Recenzja książki: Ludwik Landau, Gospodarka Światowa. Produkcja i dochód społeczny w liczbach, Warszawa 1938, Instytut Gospodarstwa Społecznego, viii+152 str., „Przegląd Statystyczny” 1 (1938), 349-359.

${ }^{6}$ Czasopismo ma tytuł „Di Jidise Ekonomik” (podtytuł Ekonomia Żydowska oraz Jewish Economics). Wydawane było w latach 1937-1939 w Wilnie przez Żydowski Instytut Naukowy (JIWO) w języku jidysz, ze streszczeniami w języku polskim. 
Ponadto Fogelson wygłosił kilka odczytów na posiedzeniach Polskiego Towarzystwa Statystycznego (PTS) w Warszawie i na konferencjach statystycznych (wypisujemy je w kolejności daty odczytu):

[F59] Sur la méthode d'inversion en statistique mathématique (odczyt na II Zjeździe Matematyków Krajów Słowiańskich w Pradze, 23-28.09.1934).

[F60] O spótczynniku korelacji (odczyt Sekcja Statystyczna Towarzystwa Ekonomistów i Statystyków Polskich 16.05.1934).

[F61] Zasadnicze cechy procesów ludnościowych na Polesiu (odczyt na pierwszym Zjeździe Sprawozdawczo-Naukowym poświęconym Ziemiom Wschodnim w Warszawie, 20-21.09.1936). W innym miejscu jest informacja, że odczyt miał tytuł Ruch naturalny ludności na Polesiu.

[F62] Les migrations et leur role démographique en Pologne (1871-1936) (odczyt na Congrès International de la Population Paris 1937).

[F63] O mierzeniu wspótzależności cech dwuwartościowych (odczyt PTS 2.06.1938).

[F64] Polskie tablice wymieralności 1931/32. Metoda i wyniki (odczyt wspólny z J. Ajdelmanem, PTS 14.12.1938).

\section{Informacje o Fogelsonie}

[1] Samuel Fogelson, akta w Archiwum Uniwersytetu Warszawskiego, sygn. RP 13096 (w tym: świadectwo urodzenia z 18 stycznia 1921, własnoręcznie pisane życiorysy z 12 października 1922 i 1 kwietnia 1927, podanie o udzielenie urlopu z 29 września 1926, wykaz wykładów i ćwiczeń na Wydziale Filozoficznym ze zdjęciem z 1 listopada 1922, wykaz wykładów i ćwiczeń na Wydziale Filozoficzno-Humanistycznym ze zdjęciem z 14 maja 1927, dowód osobisty akademicki ze zdjęciem).

[2] Samuel Fogelson, przypis 82 w: „Polskie Towarzystwo Statystyczne 1912-2012" (pod redakcją dra Kazimierza Kruszki), Polskie Towarzystwo Statystyczne, Rada Główna, Warszawa 2012, 34-35 [nieprawdziwa informacja o asystenturze na UW].

[3] Samuel Fogelson, w Wikipedii: ${ }^{7}$ (nieprawdziwa informacja o asystenturze na UW; cytowane [F4], [F13], [F25], [F47]).

[4] Lista członków Polskiego Towarzystwa Statystycznego zamordowanych lub zaginionych, "Przegląd Statystyczny” 1949, t. 3, 1-2, 3 [znajdujemy tutaj nazwisko Samuel Fogelson, mgr].

\footnotetext{
${ }^{7}$ https://pl.wikipedia.org/wiki/Samuel_Fogelson, dostęp 20.09.2016.
} 
[5] Romana Ferszt, teczka studencka nr 3560 w Archiwum UW zawierająca jej zdjęcie. Świadectwo urodzenia z 23 maja 1922, świadectwo dojrzałości z czerwca 1918 roku oraz tłumaczenie z francuskiego na polski aktu małżeństwa z 17 sierpnia 1929 roku i zaświadczenie nr 1525 o zwolnieniu z czesnego wystawione przez Wolną Wszechnicę Polską dla Romany Fogelson jako żony starszego asystenta, dokumenty w Archiwum Państwowym w Nidzicy, Zespół WWP, Wydział MatematycznoPrzyrodniczy, teczka studencka nr 203.

[6] A. Poczobut, Żywot agenta sowieckiego, „Kresy24.pl-Wschodnia Gazeta Codzienna” z 10 marca 2011 ${ }^{8,9}$ oraz "Magazyn Polski” z 12 grudnia 2008, 21-23 [nieprawdziwa informacja o asystenturze Fogelsona na UW].

[7] A. Poczobut, Siatka statystyka, „Gazeta Wyborcza” nr 234 z 7 października 2013, s. 8 [nieprawdą jest, że Fogelson robił karierę naukową na Wydziale Matematyki UW].

[8] A. Poczobut, Polscy komuniści w sowieckim raju, „Wschodnia Gazeta Codzienna", 5 maja $2014^{10}$ [nieprawdziwa informacja, że Fogelson w ciaggu 4 lat był asystentem na Wydziale Matematyki UW].

[9] E. Rosset, Rozwój polskiej myśli statystycznej. Wybór pism statystyków polskich, [w:] Polskie Towarzystwo Ekonomiczne, Warszawa 1968, 527 stron [Fogelson, str. 509-518, w tym krótka biografia Fogelsona na str. 509 oraz przedruk z prac: z [F4] strony 107-109 i 131-132 oraz z [F47] strony $14-18$ i 25 ; niepoprawny rok urodzenia powtarzany przez wielu autorów].

[10] R. Spałek, Komuniści przeciwko komunistom. Poszukiwanie wroga wewnętrznego w kierownictwie partii komunistycznej w Polsce w latach 1948-1956, Instytut Pamięci Narodowej, Wydawnictwo Zysk i S-ka, Warszawa-Poznań 2014, 1133 str. [Fogelson, str. 60-64, 68, 73, 96, $118,120,121,133,134,144,153,435$; błędny rok urodzenia i nieprawdziwa informacja o asystenturze na UW na stronie 65].

\section{Prace naukowe i książki, cytujące Fogelsona}

[11] Z. Błażyński, Mówi Józef Światło. Za kulisami bezpieki i partii 19401955, Oficyna Wydawnicza RYTM, Warszawa 1990, xv+319 str. (Fogelson, str. 149, 151).

\footnotetext{
${ }^{8}$ http://kresy24.pl/19324/zywot-agenta-sowieckiego/, dostęp 20.09.2016

${ }^{9}$ http://blogmedia24.pl/node/46108, dostęp 20.09.2016.

${ }^{10}$ http://kresy24.pl/51350/polscy-komunisci-w-sowieckim-raju, dostęp 20.09.2016.
} 
[12] Collected Works of Michal Kalecki, Vol. 1. Capitalism. Business Cycles and FM Employment, Ed. J. Osiatyński, Claredon Press, Oxford 1990; reprinted in 1998 (Fogelson, str. 443, 468-469, 471, 478, 480-1; cytuje [F29]).

[13] Demographic problems of Poland, „Population Index” 5 (1939), 4, 233238 (Fogelson, str. 233, 238).

[14] L. Dobroszycki, The fertility of modern Polish Jewry, [w:] Modern Jewish Fertility, red. Paul Ritterband, Brill, Leiden 1981, 64-77 (Fogelson, str. 64, 66, 76, 77; cytuje [F41], [F48]).

[15] C. Domański, Zastużeni statystycy dla nauki, 18 stron $^{11}$ (Fogelson, str. 14; błędny rok urodzenia; cytuje [F4], [F13], [F25], [F47]).

[16] A.G. Duker, Bibliographical notes, „The Jewish Social Service Quartely" 15 (1939), 2, 278-280 (Fogelson, str. 280; cytuje [F54]).

[17] A. Gawryszewski, Ludność Polski w XX wieku, PAN Instytut Geografii i Przestrzennego Zagospodarowania, Warszawa 2005, 627 stron (Fogelson, str. 14, 15, 64, 159, 194, 208, 216, 219, 227, 304, 409, 424, 509; cytowane prace [F11], [F33], [F40], [F45], [F48]).

[18] E.J. Gumbel, La précision de la Moyenne Arithmétique et de la Médiane, „Aktuárské védy" 6 (1936), 4, 145-154 (Fogelson, str. 147; cytuje [F1]).

[19] E.J. Gumbel, Statistics of Extremes, Dover, New York 1958; reprint 2004 (Fogelson, str. 50 i 355; cytuje [F1]), MR0096342, MR2080344.

[20] B. Łazowska, Gtówny Urzad Statystyczny w latach 1918-1939, „Wiadomości Statystyczne" 7 (2013), 1-21 (Fogelson, str. 9-11; cytuje [F4][F6], [F12], [F26], [F49]).

[21] L. Maligranda, W. Piotrowski, Aleksander Rajchman (1890-1940), „Wiadomości Matematyczne”, 28 stron, w druku (Fogelson, str. 18, 22; cytują [F29]).

[22] J. Marcus, Social and Political History of the Jews in Poland 19191939, Mouton Publishers, Berlin-New York 1983, xvii+569 str. (Fogelson, str. 171-173, 388, 490, 491, 530, 561; cytuje [F41], [F48], [F54]).

[23] H. Milicer-Grużewska, O miarach statystycznych, „Kwartalnik Statystyczny" 11 (1934), 3-4, 544-561 (Fogelson, str. 544; cytuje [F25]).

\footnotetext{
${ }^{11} \mathrm{http}: / /$ stat.gov.pl/cps/rde/xbcr/gus/POZ_Zasluzeni_statystycy_dla_nauki.pdf, dostęp 20.09.2016.
} 
[24] J. Mucha, Oblicza etniczności. Studia teoretyczne i empiryczne, NOMOS, Kraków 2005 (Fogelson, str. 268, 270, 367; cytuje [F48]).

[25] B. Ogórek, Populacja Krakowa w kontekście długofalowych procesów demograficznych na przełomie XIX $i$ XX wieku, „Przeszłość Demograficzna Polski" 32 (2013), 25-87 (Fogelson, str. 31, 40; cytuje [F38], [F51]).

[26] W. Orwicki, Program ludnościowy, Wyd. Tygodnika „Naród i Państwo", Warszawa 1939, 69 str.+6 tablic (Fogelson, str. 22, 65; cytuje [F39], [F41], [F47]).

[27] E. Stańczyk, Rodność i umieralność na ziemiach polskich w kontekście teorii przejścia demograficznego, „Wiadomości Statystyczne” 54 (2009), 9, 16-32 (Fogelson, str. 27; cytuje [F11]).

[28] S. Szulc, Metody Statystyczne, Państwowe Wydawnictwo Ekonomiczne, Warszawa 1961, 738 str. (Fogelson, str. 231, 267, 268, 270, 685; cytuje [F1], [F3], [F13], [F52]); ang. tłumaczenie Statistical Methods, Państwowe Wydawnictwo Ekonomiczne, Warsaw 1965, 666 str. (Fogelson, str. 208, 243, 244, 246 i 620; cytuje [F1], [F3], [F13], [F52]).

[29] J. Wiśniewski, Krzywa logarytmiczna i jej zastosowania, „Kwartalnik Statystyczny" 11 (1934), 2, 298-322 (Fogelson, str. 313, 318; cytuje [F13]).

[30] J. Wiśniewski, Kilka uwag o miarach korelacji, „Kwartalnik Statystyczny" 11 (1934), 3-4, 535-543 (Fogelson, str. 535-539; cytuje [F25]).

[31] T. Wysocki, Zaawansowanie przejścia demograficznego w grupach narodowościowych $i$ wyznaniowych $w$ Polsce okresu międzywojennego, „Studia Demograficzne" 153-154 (2008), 1-2, 54-81 (Fogelson, str. 56, 68; cytuje [F39], [F41]). 


\title{
Samuel Fogelson (1902 - after 1941)
}

\section{Lech Maligranda and Walerian Piotrowski}

\begin{abstract}
Samuel Fogelson is a forgotten Polish mathematician and statistician from Warsaw who was also a Soviet intelligence agent. There is no information about him in the Biographical Dictionary of Polish Mathematicians (2003) and the Polish Biographical Dictionary, but it is information in Wikipedia [3], where however it is written only on his espionage activity from the descriptions by A. Poczobut [6][8]. We want to present him as a mathematician and statistician from Warsaw, who published many papers, especially in descriptive statistics. We tried to give some of his achievements in mathematics and statistics. Also we mention briefly about his spying activities for the Soviet state.
\end{abstract}

2010 Mathematics Subject Classification: 01A72; 01A60.

Key words and phrases: statistics, biographies, Polish mathematics.

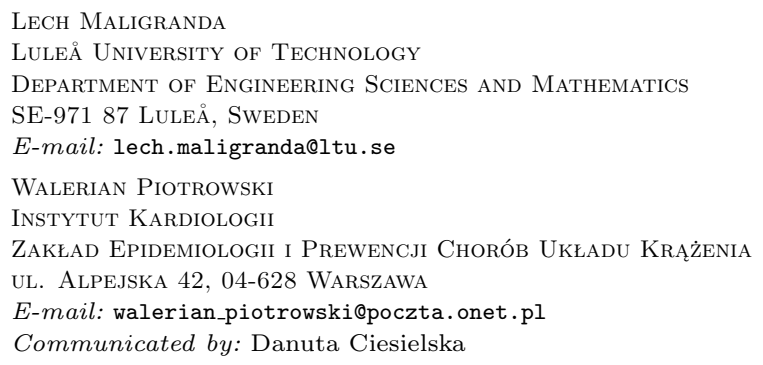

(Zgłoszona: 20 września 2016; Wersja końcowa: 20 października 2016) 